\title{
Efficiency Enhancement of Cocktail Dye of Ixora coccinea and Tradescantia spathacea in DSSC
}

\author{
Zularif Zolkepli, ${ }^{1}$ Andery Lim, ${ }^{2,3}$ Piyasiri Ekanayake,, ${ }^{2,3}$ and Kushan Tennakoon ${ }^{1,4}$ \\ ${ }^{1}$ Environmental and Life Sciences Programme, Universiti Brunei Darussalam, Jalan Tungku Link, Gadong BE1410, \\ Brunei Darussalam \\ ${ }^{2}$ Physical and Geological Sciences Programme, Universiti Brunei Darussalam, Jalan Tungku Link, Gadong BE1410, \\ Brunei Darussalam \\ ${ }^{3}$ Centre for Advanced Material and Energy Sciences (CAMES), Universiti Brunei Darussalam, Jalan Tungku Link, \\ Gadong BE1410, Brunei Darussalam \\ ${ }^{4}$ Institute for Biodiversity and Environmental Research (IBER), Universiti Brunei Darussalam, Jalan Tungku Link, \\ Gadong BE1410, Brunei Darussalam
}

Correspondence should be addressed to Piyasiri Ekanayake; piyasiri.ekanayake@ubd.edu.bn

Received 30 September 2015; Accepted 1 December 2015

Academic Editor: Jianwei Shuai

Copyright (C) 2015 Zularif Zolkepli et al. This is an open access article distributed under the Creative Commons Attribution License, which permits unrestricted use, distribution, and reproduction in any medium, provided the original work is properly cited.

The use of anthocyanin dyes extracted from epidermal leaves of Tradescantia spathacea (Trant) and petals of Ixora coccinea (IX) was evaluated in the application of dye-sensitized solar cells (DSSCs). Subsequently, cocktail anthocyanin dyes from these dyes were prepared and how they enhanced the cell's overall performance was assessed using five different volume-to-volume ratios. Cocktail dyes absorbed a wider range of light in the visible region, thus increasing the cell efficiencies of the cocktail dyes when compared to the DSSC sensitized by individual dyes. The surface charge (zeta-potential), average size of aggregated anthocyanin molecules (zetasizer), and anthocyanin stability in different storage temperatures were analyzed and recorded. Lower size of aggregated dye molecules as revealed from the cocktail dyes ensured better adsorption onto the $\mathrm{TiO}_{2}$ film. Tradescantia/Ixora pigments mixed in $1: 4$ ratio showed the highest cell efficiency of $\eta=0.80 \%$, under the irradiance of $100 \mathrm{~mW} \mathrm{~cm}{ }^{-2}$, with a short-circuit current density $4.185 \mathrm{~mA} / \mathrm{cm}^{2}$, open-circuit voltage of $0.346 \mathrm{~V}$, and fill factor of 0.499 . It was found that the desired storage temperature for these cocktail dyes to be stable over time was $-20^{\circ} \mathrm{C}$, in which the anthocyanin half-life was about approximately 1727 days.

\section{Introduction}

Dye-sensitized solar cell (DSSC) is a photovoltaic technology developed by O'Regan and Grätzel in 1991 [1], also known as Grätzel cell. DSSC is designed based on light harvesting by a sensitizing dye attached to the nanostructured semiconductor [1]. Using inorganic dyes as sensitizers had shown great potential for DSSC [1-3]. Study of DSSC using rutheniumbased complex as dye sensitizer [4] and Zn-porphyrin (dye sensitizer) with a Co-based electrolyte [5] achieved maximum efficiencies of $11.5 \%$ and $12.3 \%$, respectively.

However, due to the presence of heavy metal complexes, it poses an issue for the environment [6]. This accounts for the use of natural dyes as sensitizers in DSSC. Anthocyanin, chlorophyll, tannin, and carotene, extracted from various plants, fruits, flowers, and leaves, have been successfully used as sensitizers in DSSCs $[2,3]$. However, natural dyes as sensitizers showed quite poor performance and instabilities in DSSC. One approach in optimizing the efficiency of DSSCs is by making cocktail dye (mixing two or more dyes) to increase the absorption spectrum of the dyes [7, 8]. Mixed dyes, containing anthocyanin and betalains, had shown overall solar energy conversion efficiency of around $2 \%$ [8]. Natural dyes are relatively easy to obtain and extract from plants, reducing the cost manufacturing of DSSC, as opposed to the production of synthetic dyes [1]. Although the currently most efficient Grätzel cell is still less efficient than the standard conventional solar cell, due to the light absorption mechanism of the natural dyes, DSSCs function even in low-light conditions [9]. 
Anthocyanins are natural components that are responsible for the red-purple color of fruits, flowers, and leaves of plants. They may also present in other plant tissues such as roots, tubers, and stems $[2,3]$. They absorb light in the range of 520-550 nm wavelength [10] and are $\mathrm{pH}$ dependent, usually red in color in an acidic medium but turning into blue in less acidic condition [6]. Several factors such as light, temperature, and $\mathrm{pH}$ can destabilize the anthocyanin molecular structure [11]. Zeta-potential (surface charge), sizes of aggregated dye molecules, $\mathrm{pH}$, and conductivity can be used to determine the stability of anthocyanin [12].

In this study, the performance of a common group of natural dyes abundant in flowers and fruits, namely, anthocyanin, is evaluated in DSSCs. The natural dyes used in this study were obtained from petals of dark red colored Ixora sp. (coded as "IX") and purple lower epidermal leaves of Tradescantia sp. (coded as “Trant”).

Ixora coccinea (Rubiaceae), also known as flame of wood, is usually grown as ornamental. It is a shrub notable for its bright colored flowers, which are composed of many small blooms massed together into dense, flat-topped flower heads. The flowers contain anthocyanin and have antidiarrheal [13] and cytotoxic properties [14].

Tradescantia spathacea is an herbaceous plant that is commercially grown for bedding and rock garden. T. spathacea is a plant that adapts to low-light environment and can grow in both shade and exposed light environment. It has antiinflammatory and anticancer properties [15].

This paper describes the use of these two natural anthocyanin dyes from both plants as cocktail dye in DSSC. Cocktail dye is made by mixing two or more natural dyes together, with the aim of improving the range of absorption of light in the visible region and thus of improving the overall efficiency [16]. The effect of different volume-to-volume ratio concentrations on the photoelectric conversion efficiency of dye-sensitized solar cells is determined.

\section{Experimental Section}

2.1. Plant Materials. Petals of I. coccinea and lower epidermal leaves of $T$. spathacea were harvested to extract natural anthocyanin dyes.

2.2. Anthocyanin Extraction. $25 \mathrm{~g}$ of petals of $I$. coccinea and lower epidermal leaves of $T$. spathacea was ground with $50 \mathrm{~mL}$ of $70 \%$ ethanol and stored overnight in the refrigerator at $4^{\circ} \mathrm{C}$. On the following day, the extracted samples were stirred using magnetic stirrer for two hours. The procedure continued with the filtration of the samples to remove large residue. Subsequently, the extracts were centrifuged at $4500 \mathrm{rpm}$ using a Denley BS400 (UK) centrifuge machine for five minutes to separate any remaining residues. The next step was to purify the sample using petroleum ether to separate polar and nonpolar components of the extracted dyes.

For T. spathacea, additional steps were incorporated after the grinding and purification processes. The extract was placed in a $45-50^{\circ} \mathrm{C}$ water bath after grinding to dissolve more pigments into the extracting solvent [17] and then kept in a refrigerator at $4^{\circ} \mathrm{C}$. During the purification step, petroleum ether was first used and then diethyl ether to remove remaining impurities because it is more nonpolar than petroleum ether. The purified samples were then stored in a reagent bottle at $4^{\circ} \mathrm{C}$ for further study.

2.3. Cocktail Mixtures. The anthocyanin dyes extracted from T. spathacea (Trant) and I. coccinea (IX) were mixed at different v/v ratios to make five cocktail dye mixtures. For example, $1 \mathrm{~mL}$ of Trant was mixed with $4 \mathrm{~mL}$ of IX to make a cocktail dye $1: 4(\mathrm{v} / \mathrm{v})$. The same method was used to prepare Trant/IX cocktail dyes of ratios $2: 3(\mathrm{v} / \mathrm{v}), 1: 1(\mathrm{v} / \mathrm{v}), 3: 2(\mathrm{v} / \mathrm{v})$, and $4: 1(\mathrm{v} / \mathrm{v})$.

2.4. Anthocyanin Content Determination. The content of anthocyanin presence in the dye extract was determined using the formula described by Giusti and Wrolstad [18] based on the known fact that anthocyanin is $\mathrm{pH}$ dependent. Two dilutions of each cocktail dye were prepared before absorbance reading, one with potassium chloride buffer $(0.025 \mathrm{M}, \mathrm{pH} 1.0)$ and the other with sodium acetate buffer $(0.4 \mathrm{M}, \mathrm{pH} 4.5)$. The preparation of the reagents was described elsewhere [19]. The absorbance was read at $520 \mathrm{~nm}$ and $700 \mathrm{~nm}$ against a blank cell containing $70 \%$ of ethanol using UV-Vis spectrophotometer (Shimadzu UV1800, Japan). The monomeric anthocyanin pigment content in the original sample was calculated according to the following formula:

anthocyanin pigment content

$$
=\frac{A \times \mathrm{MW} \times \mathrm{DF} \times 10^{3}}{\varepsilon \times l},
$$

where $A=\left(A_{520 \mathrm{~nm}}-A_{700 \mathrm{~nm}}\right)$ at $\mathrm{pH} 1.0-\left(A_{520 \mathrm{~nm}}-\right.$ $A_{700 \mathrm{~nm}}$ ) at $\mathrm{pH} 4.5$, MW (Molecular Weight) is $449.2 \mathrm{~g} / \mathrm{mol}$ for cyaniding-3-glucoside, DF is dilution factor, $10^{3}$ is factor for conversion from $\mathrm{g}$ to $\mathrm{mg}, \varepsilon$ is $26900 \mathrm{~L} \mathrm{~mol}^{-1} \mathrm{~cm}^{-1}$, and $l$ is the assumed path length of incident light in $\mathrm{cm}$.

2.5. Anthocyanin Absorption Spectrum. Presence of anthocyanin pigments was determined by measuring their absorbance spectra using UV-Vis spectrophotometer (Shimadzu UV-1800, Japan). Pretreated dye extracts with and without concentrated $\mathrm{HCl}$ acid were examined in the characterization. Each measurement was repeated thrice to confirm the accuracy of readings.

2.6. Zeta-Potential and Zetasizer. The zeta-potential and zetasizer of the individual dyes and cocktail mixtures were measured using Malvern Zetasizer (Nano MAN 0317) at a temperature of $25^{\circ} \mathrm{C}$ in $70 \%$ of ethanol solution. Each measurement was repeated thrice to confirm the accuracy of readings.

2.7. Dye-Sensitized Solar Cell Preparation and I-V Characterization. A conductive glass (FTO) containing sintered 


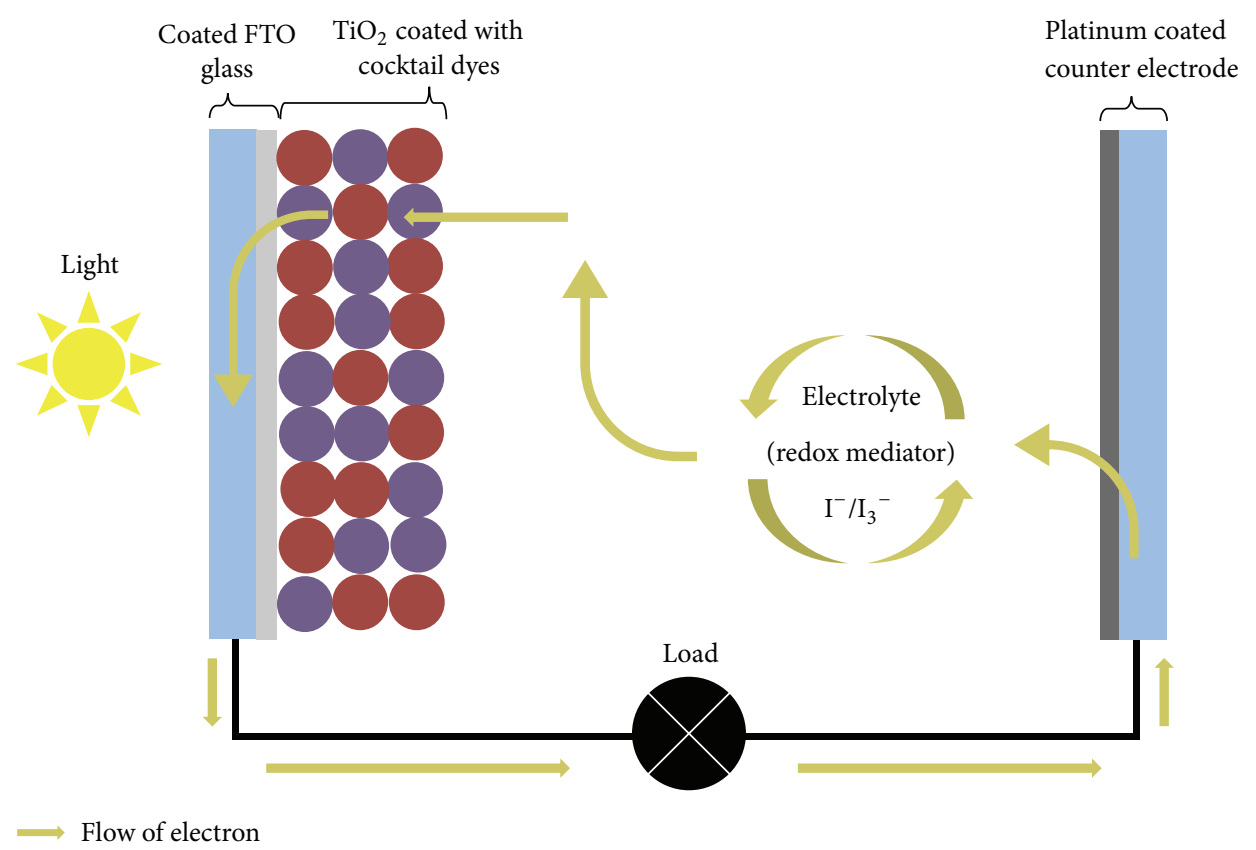

FIGURE 1: The absorption spectra of the extracts of Tradescantia spathacea (Trant) and Ixora coccinea (IX) in original and acidified extract.

$\mathrm{TiO}_{2}$ was prepared as the photoanode. The photoelectrodes (anodes) were fabricated using a $\mathrm{TiO}_{2}$ paste Solaronix (nanoxide-T, colloidal anatase particles size: $\sim 13 \mathrm{~nm}$, $\sim 120 \mathrm{~m}^{2} \mathrm{~g}^{-1}$ (BET), Switzerland). The $\mathrm{TiO}_{2}$ was coated on precleaned fluorine-doped conducting tin oxide (FTO) glasses (Nippon Sheet Glass $\sim 7 \Omega \mathrm{sq}^{-1}$ ) by doctor blade method. Electrodes were preheated $\left(\sim 50^{\circ} \mathrm{C}\right)$ using a hair dryer and sintered at $450^{\circ} \mathrm{C}$ for 30 minutes. The thickness of the $\mathrm{TiO}_{2}$ electrodes used for this investigation was $\sim 9 \mu \mathrm{m}$ (Scanning Electron Microscope, SEM) [20]. The anodes were dipped in respective dye solutions (Trant, IX, and the cocktail dyes) as the photosensitizers. These were left submerged approximately for 16 hours at room temperature in the dark to avoid light exposure. This allows enough time for the dyes to adsorb onto the $\mathrm{TiO}_{2}$ porous layer. The anodes were then rinsed with ethanol and air dried. Electrolyte, containing tetrabutylammonium iodide (TBAI, $0.5 \mathrm{M}) / I_{2}(0.05 \mathrm{M})$, in a mixture of acetonitrile and ethylene carbonate $(6: 4, \mathrm{v} / \mathrm{v})$, was then introduced between the dyed $\mathrm{TiO}_{2}$ electrode and platinum counter electrode [21]. These DSSCs were placed under irradiation of light $\left(100 \mathrm{~mW} / \mathrm{cm}^{2}\right)$ using sun simulator (DYESOL) for about 4 hours for better incorporation of electrolyte into the $\mathrm{TiO}_{2}$ layer [22]. Figure 1 shows a schematic diagram of a functioning DSSC. The performance of the cell in terms of energy conversion efficiency $(\eta)$ was evaluated by using relation of short-circuit current $\left(I_{\mathrm{sc}}\right)$, open-circuit voltage $\left(V_{\mathrm{oc}}\right)$, and fill factor $(\mathrm{FF})$ as shown below:

$$
(\eta)=\mathrm{FF} \times I_{\mathrm{sc}} \times \frac{V_{\mathrm{oc}}}{P},
$$

where $I_{\mathrm{sc}}$ is the short-circuit photocurrent density $\left(\mathrm{A} \mathrm{cm}^{-2}\right)$, $V_{\text {oc }}$ is the open-circuit voltage $(V), P$ is the intensity of the incident light $\left(\mathrm{W} \mathrm{cm}^{-2}\right)$, and FF is the fill factor defined as
$\mathrm{FF}=I_{m} V_{m} / I_{\mathrm{sc}} V_{\mathrm{oc}}$, in which $I_{m}$ and $V_{m}$ are the optimum photocurrent and voltage that can be extracted from the maximum power calculated from the $I-V$ data [20].

2.8. Effect of Storage Temperature on Anthocyanin Degradation. A cocktail dye mixture that showed higher conversion efficiency was selected for further evaluation on the impacts of varying temperature regimes for anthocyanin storage. The extracts were stored in enclosed glass bottles to avoid exposure to light at three different storage temperatures $-20^{\circ} \mathrm{C}, 4^{\circ} \mathrm{C}$, and $25^{\circ} \mathrm{C}$. In order to determine the anthocyanin contents, the spectroscopic absorbance of the extracts was initially determined for three consecutive days followed by weekly measurements over a period of one month followed by a final measurement after a 2 -month period.

Kinetic parameters of anthocyanin degradation were calculated using the following formulae [23]:

$$
\begin{aligned}
\ln \left(\frac{C_{t}}{C_{0}}\right) & =-k \times t, \\
t_{1 / 2} & =-\frac{\ln (0.5)}{k},
\end{aligned}
$$

where $C_{0}$ is initial anthocyanin content and $C_{t}$ anthocyanin content after $t$-minute storage at the given temperature.

\section{Results and Discussion}

3.1. UV-Vis Characterization. The presence of anthocyanin dyes was confirmed using UV-visible spectrophotometer, where peaks at $525 \mathrm{~nm}$ and $540 \mathrm{~nm}$ after acidification of IX and Trant dyes, respectively, indicate the presence of anthocyanidin (see Figure 2) [24]. Acids remove the sugar 


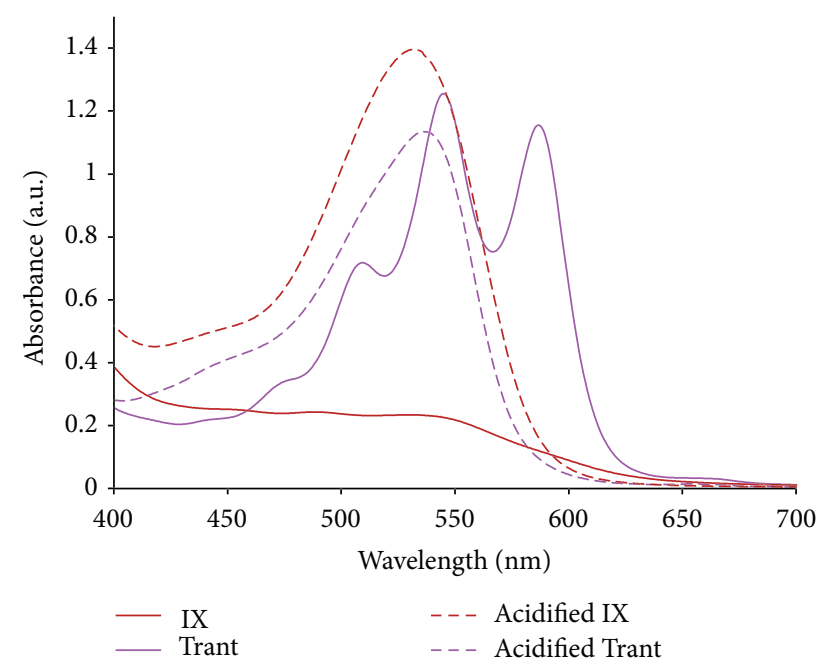

FIGURE 2: Schematic diagram of a working DSSC.

component, which converts anthocyanin into anthocyanidin that give absorption spectra peaks in the region of 490 $570 \mathrm{~nm}$ [25]. The three distinct peaks at $511 \mathrm{~nm}, 548 \mathrm{~nm}$, and $588 \mathrm{~nm}$ of the Trant curve suggested that the extracts might as well contain chlorophylls, which is absorbed most strongly in the blue and red regions of the absorption spectra.

Figure 3(a) shows the absorption spectra for five cocktail dye mixtures before the adsorption of dyes onto the $\mathrm{TiO}_{2}$ paste. The figure shows the maximum absorption peak for all cocktail dye mixtures at $550 \mathrm{~nm}$, and for the cocktail mixture, the absorption range varies within $490 \sim 650 \mathrm{~nm}$. Figure 3(b) shows the absorption spectra for five cocktail dye mixtures after adsorption onto the $\mathrm{TiO}_{2}$ paste. Results show that the cocktail dyes after adsorption onto $\mathrm{TiO}_{2}$ paste have increased the range of the absorption wavelength and have allowed further absorption of more visible light. This has led to further increase of the photoelectric conversion efficiency of the DSSC. The highest absorbance readings were from cocktail mixture Trant/IX 1:4, which contains more IX, while the lowest absorbance readings were from cocktail mixture Trant/IX 4:1, which had the lowest concentration of IX among the mixtures. The absorption readings have decreased as the concentrations of Trant to IX increased. This shows that $\mathrm{TiO}_{2}$ dyed with IX might have better absorption capability compared to $\mathrm{TiO}_{2}$ dyed with Trant, and this can be attributed to its homogeneous adsorption onto the $\mathrm{TiO}_{2}$ surface that increases the absorption of light in the visible region [2].

3.2. Zeta-Potential and Zetasizer. Experimental results showed that average zeta-potentials of anthocyanin extracted from IX, Trant, and the cocktail mixtures prepared using different ratios of these pigment extracts occurred between $-0.4 \mathrm{mV}$ and $-0.9 \mathrm{mV}$ (Figure $4(\mathrm{a})$ ). This value indicates a high possibility for all tested anthocyanin dyes undergoing molecular aggregations and showing increased instability of colloids. This is because the least stable colloidal systems have no force to repel molecule that can cause high
TABLE 1: The photoelectric parameters of DSSCs sensitized with natural dyes extracted from the lower epidermis of Tradescantia spathacea leaves (Trant) and flowers of Ixora coccinea (IX).

\begin{tabular}{lcccc}
\hline Dyes & $V_{\text {oc }}(\mathrm{V})$ & $J_{\text {sc }}\left(\mathrm{mA} / \mathrm{cm}^{2}\right)$ & $\mathrm{FF}$ & $\eta(\%)$ \\
\hline $\begin{array}{l}\text { Individual dyes } \\
\quad \text { Trant }\end{array}$ & 0.285 & 1.189 & 0.554 & $0.21 \pm 0.02$ \\
$\quad$ IX & 0.344 & 3.005 & 0.507 & $0.56 \pm 0.02$ \\
$\begin{array}{l}\text { Cocktail dyes } \\
\text { (Trant/IX) }\end{array}$ & & & & \\
$1: 4$ & 0.346 & 4.185 & 0.499 & $0.80 \pm 0.02$ \\
$2: 3$ & 0.343 & 3.780 & 0.492 & $0.71 \pm 0.02$ \\
$1: 1$ & 0.331 & 3.150 & 0.502 & $0.59 \pm 0.02$ \\
$3: 2$ & 0.359 & 2.914 & 0.492 & $0.61 \pm 0.02$ \\
$4: 1$ & 0.344 & 2.074 & 0.520 & $0.41 \pm 0.02$ \\
\hline
\end{tabular}

charge transfer resistance that in turn hinders the electron injection efficiency during the $I-V$ performance $[26,27]$. The aggregation could also result in poor physical contacts between the anthocyanins pigment and the $\mathrm{TiO}_{2}$ layer, which causes desorption of dyes from the $\mathrm{TiO}_{2}$ layer [28].

As depicted in Figure 4(b), the average size of aggregated dye molecules of Trant is $34900 \mathrm{~nm}$ while IX dyes reached a dimension of $2810 \mathrm{~nm}$. However, all the cocktail dyes had average sizes in the range of 2500 to $5120 \mathrm{~nm}$, approximately 6 to 7 times lower when compared to the individual pigment of anthocyanins extracted from T. spathacea. The small aggregated sizes indicate an increase in the surface area and thus, a large amount of the dyes can adsorb onto the $\mathrm{TiO}_{2}$. This resulted in the increased absorption by the dyes as shown in the absorption spectra of IX and cocktail mixtures of Figures 3(a) and 3(b) and increased efficiencies of DSSC prepared by cocktail dye mixtures (see Table 1). Hwang et al. have reported that the photocurrent densities increase with higher adsorption of dyes that may in turn give superior characters to DSSCs owing to the low charge transfer resistance from the monolayer adsorption [29].

3.3. I-V Plot. Figure 5 and Table 1 show the photoelectrical parameters for a DSSC that is sensitized using five cocktail dye mixtures from anthocyanins pigment extracted from lower epidermis of T. spathacea leaves and I. coccinea flowers. Compared to the individual dyes, cocktail dyes exhibit reasonable conversion efficiencies. This is attributed to better absorption intensity, and the absorption wavelength range is broader than in those individual dyes' extract only (Figure 3). Similar results were reported by Kimpa et al. [30], who also studied the performance of cocktail dye in DSSC, where sensitized cocktail dye has exhibited better result than individual dye alone. It is also evident that the short-circuit current or the open-circuit voltage of DSSC sensitized by the individual dyes is lower than that sensitized by the cocktail dyes. Therefore, the efficiencies of photoelectric conversion of DSSC sensitized by the cocktail dyes are higher than the individual dye (Trant and IX) constituents. 


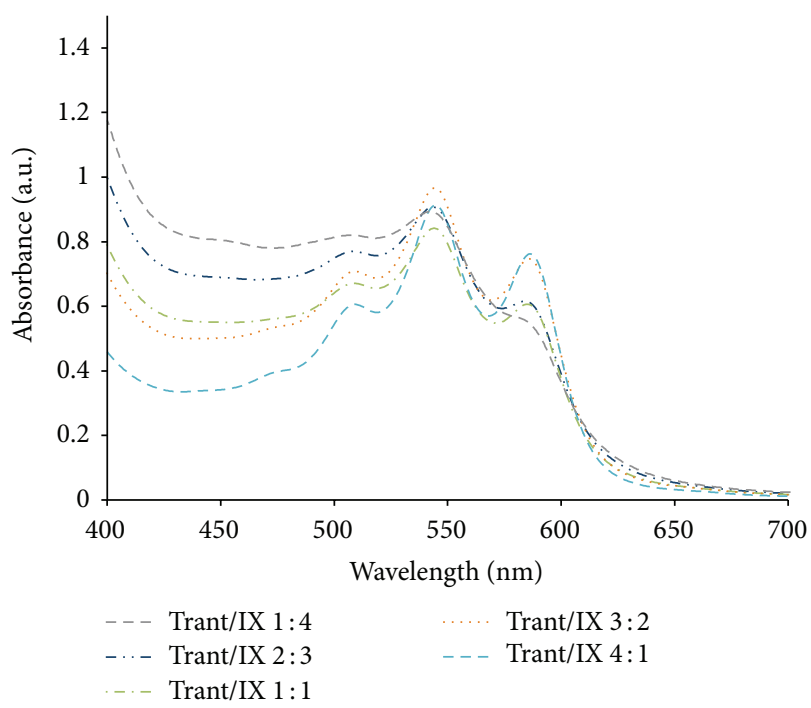

(a)

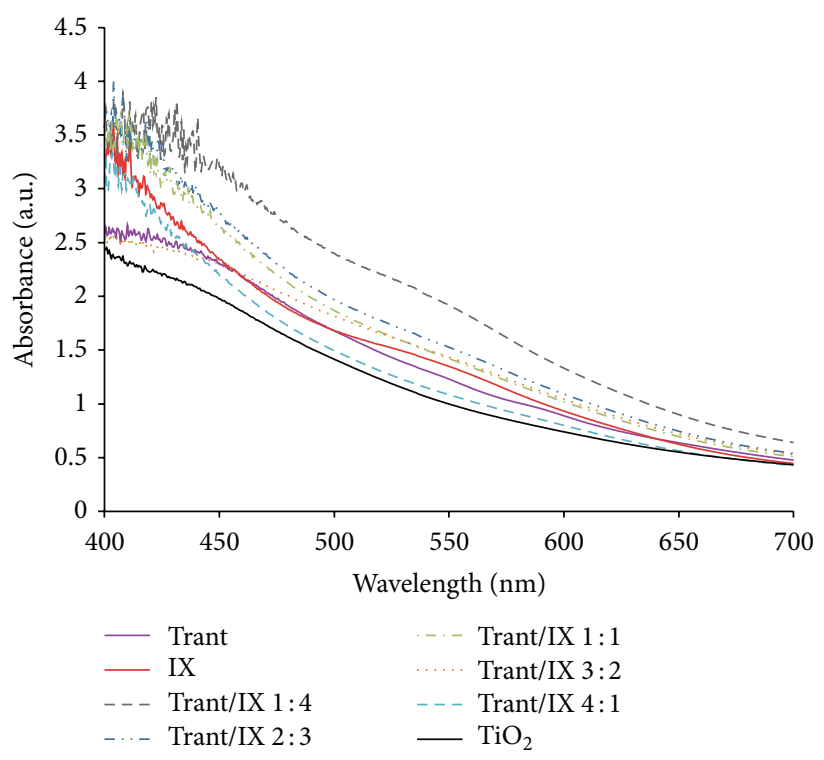

(b)

FIGURE 3: The absorption spectra of cocktail dyes Tradescantia spathacea (Trant) and Ixora coccinea (IX) (a) before and (b) after adsorption onto $\mathrm{TiO}_{2}$ film.

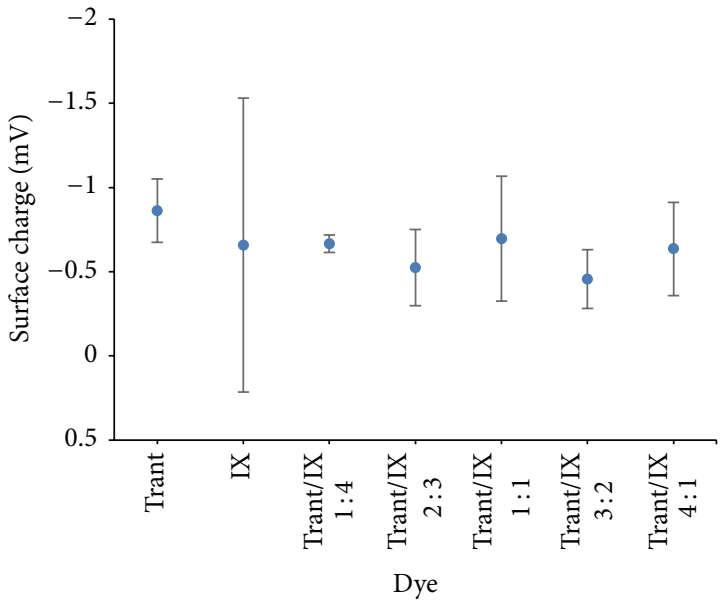

(a)

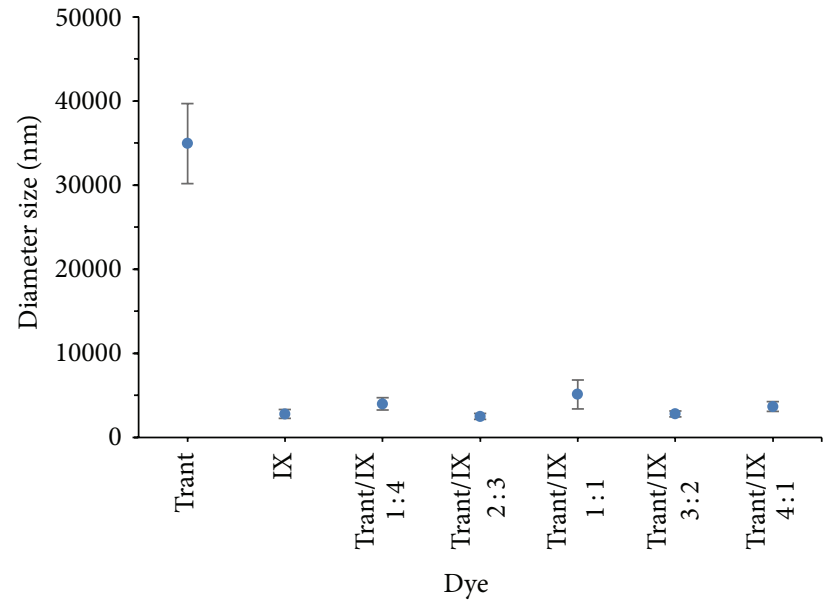

(b)

FIGURE 4: (a) Zeta-potential and (b) zetasizer of individual anthocyanin dyes extracted from Tradescantia spathacea (Trant) and Ixora coccinea (IX) and cocktail mixtures prepared from different combinations of these pigment extracts.

DSSC sensitized with cocktail dye ratio $1: 4(\mathrm{v} / \mathrm{v})$ produces the highest $I-V$ performance with $\eta=0.80 \%$ with open-circuit voltage $\left(V_{\mathrm{oc}}\right)$ of $0.343 \mathrm{~V}$, current density $\left(J_{\mathrm{sc}}\right)$ of $4.185 \mathrm{~mA} / \mathrm{cm}^{2}$, and fill factor of 0.499 , under the irradiance of $100 \mathrm{~mW} \mathrm{~cm}^{-2}$. This might be due to the lower concentration of Trant to IX in the cocktail dye ratio 1: 4 (v/v). IX better performance than Trant in DSSC might be because anthocyanin of I. coccinea favors a monolayer adsorption, which optimizes the DSSC efficiency [29,31], and homogeneous adsorption on the $\mathrm{TiO}_{2}$ surface [6].

3.4. Photodegradation Kinetics. Stability of the anthocyanin pigment in the cocktail dye mixture Trant/IX 1:4 was relatively high when they were stored at $-20^{\circ} \mathrm{C}$ and $4^{\circ} \mathrm{C}$ but decreased progressively when pigments were stored at $25^{\circ} \mathrm{C}$ over a two-month period (see Table 2 and Figure 6). The cocktail mixture was shown to be most stable when stored at $-20^{\circ} \mathrm{C}$ with a percentage loss of $2.53 \%$, followed by the storage at $4^{\circ} \mathrm{C}(4.72 \%)$ and $25^{\circ} \mathrm{C}(28.20 \%)$, respectively.

Result showed significantly faster anthocyanin degradation rates when they were stored at $25^{\circ} \mathrm{C}$. The degradation rates are represented by half-life $\left(t_{1 / 2}\right)$ values; the higher the half-life value, the slower the degradation rate. The highest half-life period (1727.05 days) was recorded from anthocyanin pigments which was in the cocktail dye mixture Trant/IX 1:4 stored at $-20^{\circ} \mathrm{C}$. The half-life was reduced to 133.88 days, when it was stored at $25^{\circ} \mathrm{C}$ over a period of two months. 
TABLE 2: Kinetic parameters of anthocyanin degradation in cocktail dye mixture of Tradescantia spathacea (Trant) and Ixora coccinea (IX) in $1: 4$ ratio at three different storage temperatures $\left(-20^{\circ} \mathrm{C}, 4^{\circ} \mathrm{C}\right.$, and $\left.25^{\circ} \mathrm{C}\right)$.

\begin{tabular}{lcccc}
\hline Temperature $\left({ }^{\circ} \mathrm{C}\right)$ & Initial conc. $(\mathrm{mg} / \mathrm{L})$ & Final conc. $(\mathrm{mg} / \mathrm{L})$ & Percentage loss $(\%)$ & $t_{1 / 2}($ day $)$ \\
\hline-20 & 322.96 & 314.77 & 2.53 & 1727.05 \\
-4 & 297.24 & 283.21 & 4.72 & 917.48 \\
25 & 272.36 & 195.54 & 28.20 & 133.88 \\
\hline
\end{tabular}

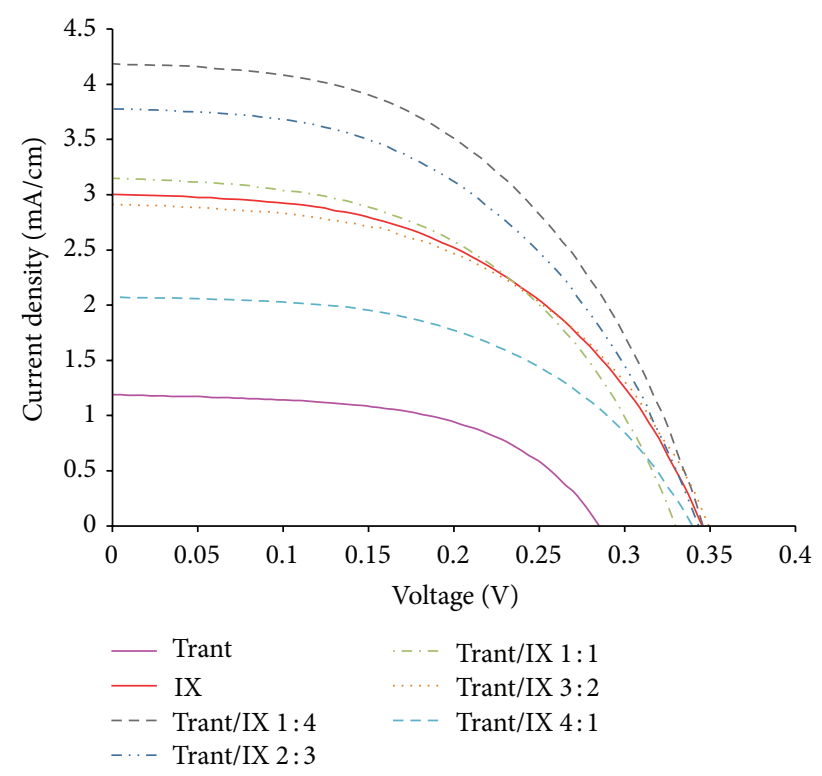

Figure 5: Current-voltage characteristics of the DSSCs sensitized with anthocyanin extracted from Tradescantia spathacea leaves (Trant) and Ixora coccinea flowers (IX).

Previous study of pigments from Melastoma malabathricum, Hibiscus rosa-sinensis, and Codiaeum variegatum stored at $-20^{\circ} \mathrm{C}$ showed $t_{1 / 2}$ values of $539.13,336.37$, and 405.72 days, respectively. The $t_{1 / 2}$ values of those pigments which were stored at $25^{\circ} \mathrm{C}$ were markedly reduced to $110.71,219.74$, and 254.25 days, respectively [2]. Kirca and Cemeroğlu also have suggested that the lowest storage temperature should be used where possible to minimize the anthocyanin degradation [32]. This is in line with our observations where the most stable anthocyanin extracts of cocktail dyes have been obtained when they had been stored at $-20^{\circ} \mathrm{C}$ over a period of two months.

\section{Conclusions}

Five cocktail mixtures (different v/v ratios) of dyes extracted from Ixora coccinea (IX) flower petals and Tradescantia spathacea (Trant) lower epidermal peels were assessed as potential candidates to increase the efficiency in DSSCs. Zeta-potential study revealed that the cocktail dyes have a tendency to agglomerate. The aggregated molecule sizes were determined (between 2500 and $5120 \mathrm{~nm}$ ) in cocktail dyes. Smaller sized aggregated dye molecules aid in the adsorption of dyes onto the $\mathrm{TiO}_{2}$ layer of DSSC. Cocktail dyes exhibited

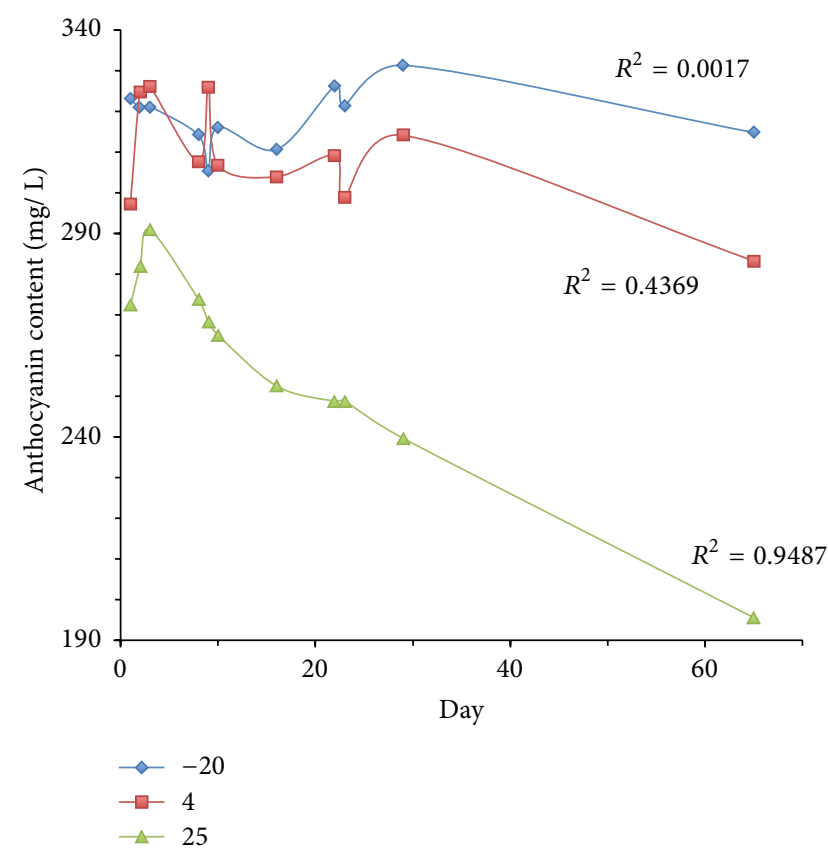

FIGURE 6: Degradation of anthocyanin pigments of cocktail dye mixture of Tradescantia spathacea (Trant) and Ixora coccinea (IX) in $1: 4$ ratio at three different storage temperatures $\left(-20^{\circ} \mathrm{C}, 4^{\circ} \mathrm{C}\right.$, and $25^{\circ} \mathrm{C}$ ) over a two-month period.

higher conversion efficiencies than the pigments extracted from IX flowers and Trant leaves individually. Thus, this work shows the effectiveness of cocktail sensitizers in DSSCs. Best overall energy conversion efficiency $(\eta=0.80 \%)$ was obtained from the DSSC sensitized with the cocktail prepared in the Trant/IX ratio $1: 4(\mathrm{v} / \mathrm{v})$. This cocktail dye was most stable when stored at $-20^{\circ} \mathrm{C}$. Modifications of cocktail dyes as reported here will further enhance the stability of zeta-potential to further increase the affinity of the dyes onto $\mathrm{TiO}_{2}$ nanocrystalline thin films. Although the solar-toelectrical energy conversion efficiencies recorded here were lower than those measured for silicon based solar cells, our DSSC developed with a cocktail dye mixture prepared using two tropical plant sources shows promising potential for further improvements in relation to its efficiency, stability, and commercialization.

\section{Conflict of Interests}

The authors declare that there is no conflict of interests regarding the publication of this paper. 


\section{Acknowledgment}

Brunei Research Council Science and Technology Research Grant (S \& T 17) is acknowledged for financial support.

\section{References}

[1] B. O’Regan and M. Grätzel, "A low-cost, high-efficiency solar cell based on dye-sensitized colloidal $\mathrm{TiO}_{2}$ films," Nature, vol. 353, no. 6346, pp. 737-740, 1991.

[2] A. Yusoff, N. T. R. N. Kumara, A. Lim, P. Ekanayake, and K. U. Tennakoon, "Impacts of temperature on the stability of tropical plant pigments as sensitizers for dye sensitized solar cells," Journal of Biophysics, vol. 2014, Article ID 739514, 8 pages, 2014.

[3] H. Chang and Y.-J. Lo, "Pomegranate leaves and mulberry fruit as natural sensitizers for dye-sensitized solar cells," Solar Energy, vol. 84, no. 10, pp. 1833-1837, 2010.

[4] C.-Y. Chen, M. Wang, J.-Y. Li et al., "Highly efficient lightharvesting ruthenium sensitizer for thin-film dye-sensitized solar cells," ACS Nano, vol. 3, no. 10, pp. 3103-3109, 2009.

[5] A. Yella, H. W. Lee, H. N. Tsao et al., "Porphyrin-sensitized solar cells with cobalt (II/III)-based redox electrolyte exceed 12 percent efficiency," Science, vol. 334, pp. 629-634, 2011.

[6] N. T. R. N. Kumara, P. Ekanayake, A. Lim et al., "Layered cosensitization for enhancement of conversion efficiency of natural dye sensitized solar cells," Journal of Alloys and Compounds, vol. 581, pp. 186-191, 2013.

[7] A. Lim, N. H. Manaf, K. Tennakoon et al., "Higher performance of DSSC with dyes from Cladophora sp. as mixed cosensitizer through synergistic effect," Journal of Biophysics, vol. 2015, Article ID 510467, 8 pages, 2015.

[8] G. Calogero, J.-H. Yum, A. Sinopoli, G. Di Marco, M. Grätzel, and M. K. Nazeeruddin, "Anthocyanins and betalains as lightharvesting pigments for dye-sensitized solar cells," Solar Energy, vol. 86, no. 5, pp. 1563-1575, 2012.

[9] H. Hug, M. Bader, P. Mair, and T. Glatzel, "Biophotovoltaics: natural pigments in dye-sensitized solar cells," Applied Energy, vol. 115, pp. 216-225, 2014.

[10] W. Wu, F. Meng, J. Li, X. Teng, and J. Hua, "Co-sensitization with near-IR absorbing cyanine dye to improve photoelectric conversion of dye-sensitized solar cells," Synthetic Metals, vol. 159, no. 11, pp. 1028-1033, 2009.

[11] I. Iosub, F. Kajzar, M. Makowska-Janusik, A. Meghea, A. Tane, and I. Rau, "Electronic structure and optical properties of some anthocyanins extracted from grapes," Optical Materials, vol. 34, no. 10, pp. 1644-1650, 2012.

[12] J. Sonnefeld, M. Löbbus, and W. Vogelsberger, "Determination of electric double layer parameters for spherical silica particles under application of the triple layer model using surface charge density data and results of electrokinetic sonic amplitude measurements," Colloids and Surfaces A: Physicochemical and Engineering Aspects, vol. 195, no. 1-3, pp. 215-225, 2001.

[13] Y. Maniyar, P. Bhixavatimath, and N. V. Agashikar, "Antidiarrheal activity of flowers of Ixora coccinea Linn. in rats," Journal of Ayurveda and Integrative Medicine, vol. 1, no. 4, pp. 287-291, 2010.

[14] P. G. Latha and K. R. Panikkar, "Cytotoxic and antitumour principles from Ixora caccinea flowers," Cancer Letters, vol. 130, no. 1-2, pp. 197-202, 1998.
[15] J. C. Kurian, T. I. Varghese, and D. Isaiah, Amazing Healing Plants, Philippine Publishing House, JC Kurian Publishing, Caloocan, Philippines, 2010.

[16] Y. Ogomi, S. S. Pandey, S. Kimura, and S. Hayase, "Probing mechanism of dye double layer formation from dye-cocktail solution for dye-sensitized solar cells," Thin Solid Films, vol. 519, no. 3, pp. 1087-1092, 2010.

[17] R. Delpech, "The importance of red pigments to plant life: experiments with anthocyanins," Journal of Biological Education, vol. 34, no. 4, pp. 206-210, 2000.

[18] M. M. Giusti and R. E. Wrolstad, "Characterization and measurement of anthocyanin by UV-visible spectroscopy," in Current Protocols in Food Analytical Chemistry, pp. F1.2.1F1.2.13, John Wiley \& Sons, New York, NY, USA, 2001.

[19] J. Lee, R. W. Durst, and R. E. Wrolstad, "Determination of total monomeric anthocyanin pigment content of fruit juices, beverages, natural colorants, and wines by the $\mathrm{pH}$ differential method: collaborative study," Journal of AOAC International, vol. 88, no. 5, pp. 1269-1278, 2005.

[20] A. Lim, N. T. R. N. Kumara, A. L. Tan et al., "Potential natural sensitizers extracted from the skin of Canarium odontophyllum fruits for dye-sensitized solar cells," Spectrochimica Acta Part A: Molecular and Biomolecular Spectroscopy, vol. 138, pp. 596-602, 2015.

[21] J. M. R. C. Fernando and G. K. R. Senadeera, "Natural anthocyanins as photosensitizers for dye-sensitized solar devices," Current Science, vol. 95, no. 5, pp. 663-666, 2008.

[22] A. C. M. S. Esteban and E. P. Enriquez, "Graphene-anthocyanin mixture as photosensitizer for dye-sensitized solar cell," Solar Energy, vol. 98, pp. 392-399, 2013.

[23] M. Kopjar, V. Piližota, D. Šubarić, and J. Babić, "Prevention of thermal degradation of red currant juice anthocyanins by phenolic compounds addition," Croatian Journal of Food Science and Technology, vol. 1, no. 1, pp. 24-30, 2009.

[24] M. R. Narayan, "Review: dye sensitized solar cells based on natural photosensitizers," Renewable and Sustainable Energy Reviews, vol. 16, no. 1, pp. 208-215, 2012.

[25] N. T. R. N. Kumara, P. Ekanayake, A. Lim, M. Iskandar, and L. C. Ming, "Study of the enhancement of cell performance of dye sensitized solar cells sensitized with Nephelium lappaceum (F: Sapindaceae)," Journal of Solar Energy Engineering, vol. 135, no. 3, Article ID 031014, 5 pages, 2013.

[26] P. Hoelttae, M. Hakanen, and M. Lahtinen, Silica Colloids and Their Effect on Radionuclide Sorption-Experimental Study, Posiva Oy, Helsinki, Finland, 2009.

[27] R. Katoh, A. Furube, A. V. Barzykin, H. Arakawa, and M. Tachiya, "Kinetics and mechanism of electron injection and charge recombination in dye-sensitized nanocrystalline semiconductors," Coordination Chemistry Reviews, vol. 248, no. 1314, pp. 1195-1213, 2004.

[28] H. Xu, X. Tao, D.-T. Wang, Y.-Z. Zheng, and J.-F. Chen, "Enhanced efficiency in dye-sensitized solar cells based on $\mathrm{TiO}_{2}$ nanocrystal/nanotube double-layered films," Electrochimica Acta, vol. 55, no. 7, pp. 2280-2285, 2010.

[29] K.-J. Hwang, S.-H. Jung, D.-W. Park, S.-J. Yoo, and J.-W. Lee, "Heterogeneous ruthenium dye adsorption on nano-structured $\mathrm{TiO}_{2}$ films for dye-sensitized solar cells," Current Applied Physics, vol. 10, no. 2, pp. S184-S187, 2010.

[30] M. I. Kimpa, M. Momoh, K. U. Isah, H. N. Yahya, and M. M. Ndamitso, "Photoelectric characterization of dye sensitized solar cells using natural dye from pawpaw leaf and flame tree 
flower as sensitizers," Materials Sciences and Applications, vol. 3 , no. 5, pp. 281-286, 2012.

[31] A. Hagfeldt and M. Grätzel, "Molecular photovoltaics," Accounts of Chemical Research, vol. 33, no. 5, pp. 269-277, 2000.

[32] A. Kırca and B. Cemeroğlu, "Degradation kinetics of anthocyanins in blood orange juice and concentrate," Food Chemistry, vol. 81, no. 4, pp. 583-587, 2003. 

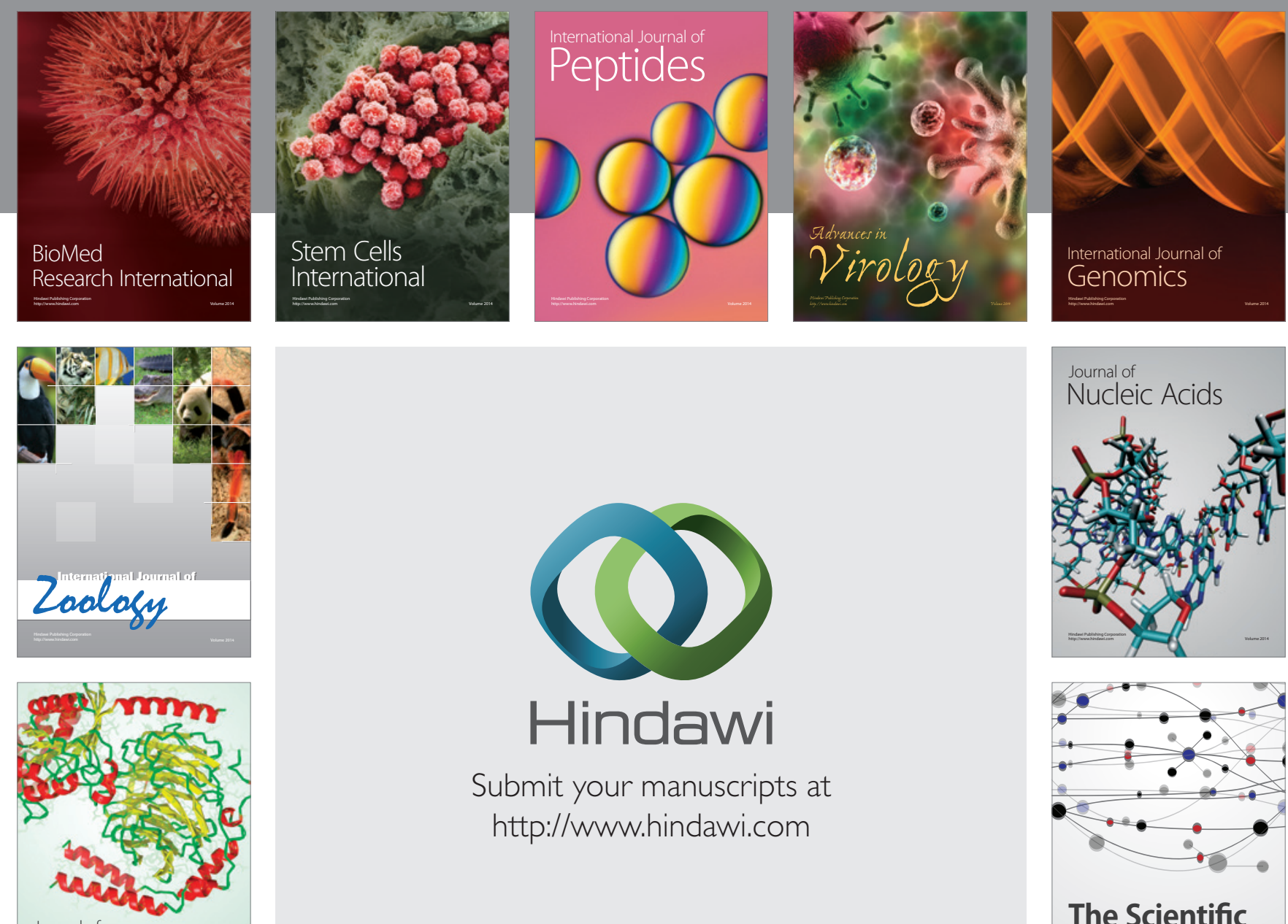

Submit your manuscripts at

http://www.hindawi.com

Journal of
Signal Transduction
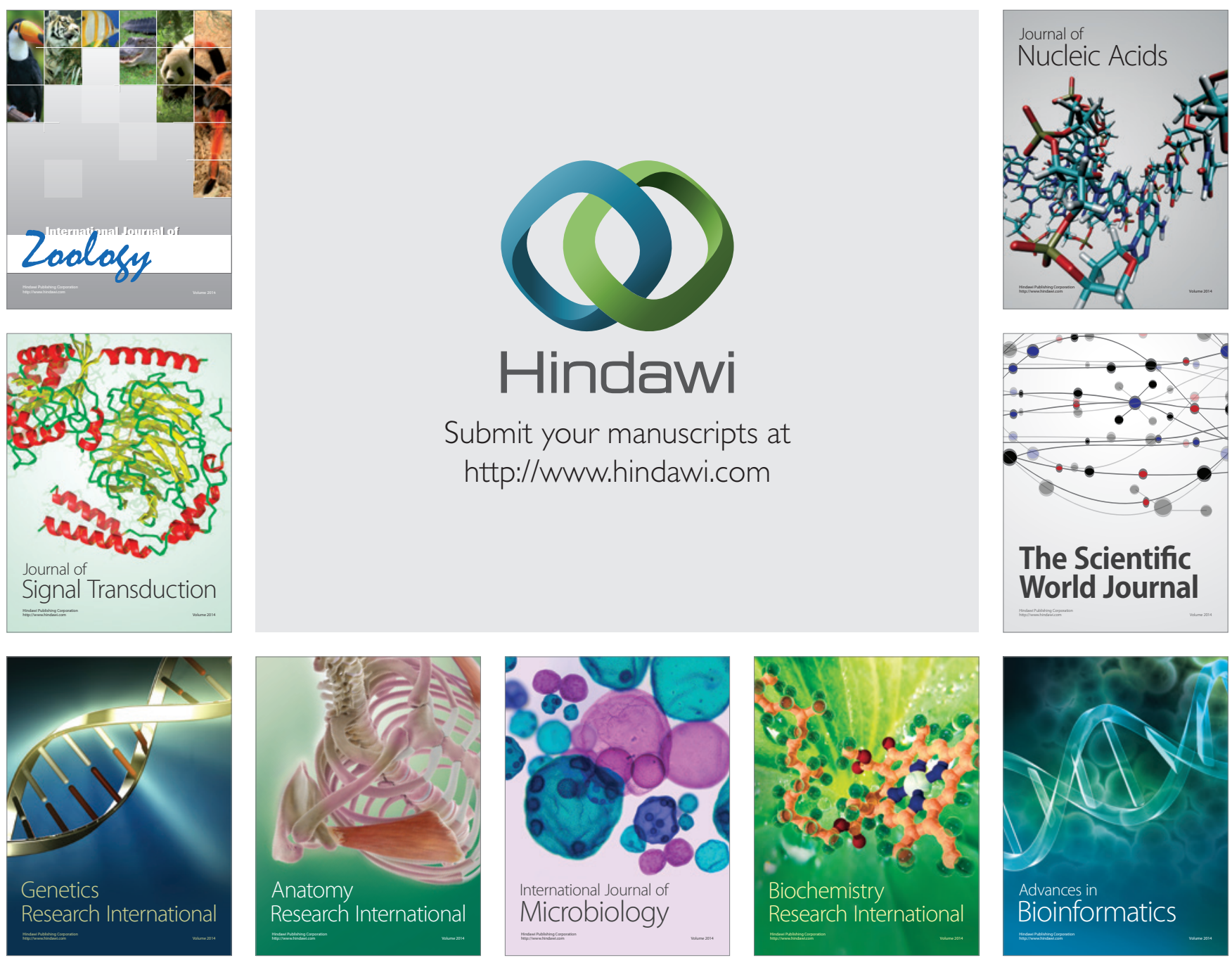

The Scientific World Journal
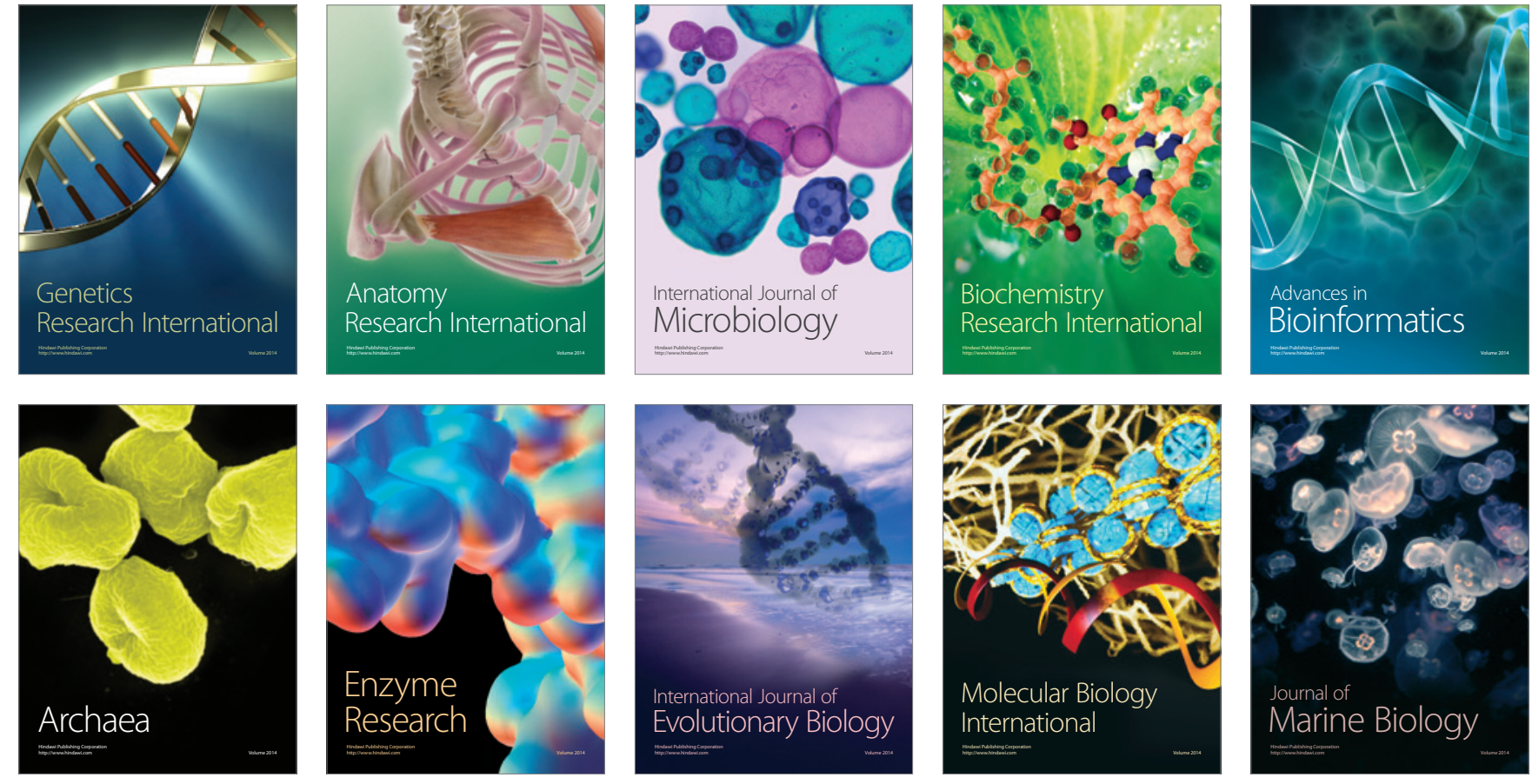